\title{
A typological perspective on negation in Finnish dialects
}

\section{Miestamo, Matti}

2011

Miestamo , M 2011 , ' A typological perspective on negation in Finnish dialects ' , Nordic

journal of linguistics, vol. 34 , no. 2 , pp. 83-104 . https://doi.org/10.1017/S0332586511000126

http://hdl.handle.net/10138/166066

https://doi.org/10.1017/S0332586511000126

acceptedVersion

Downloaded from Helda, University of Helsinki institutional repository.

This is an electronic reprint of the original article.

This reprint may differ from the original in pagination and typographic detail.

Please cite the original version. 
Pre-publication version, published in NJL 34.2 / 2011.

Miestamo, Matti. 2011. A typological perspective on negation in Finnish dialects. Nordic Journal of Linguistics 00(0), 000-000.

\section{A typological perspective on negation in Finnish dialects}

\section{Matti Miestamo}

Abstract: This paper looks at negation in Finnish dialects from a typological perspective. The focus is on standard negation, i.e. the negation of declarative verbal main clauses. The dialectal variation Finnish shows in its negative construction is examined in the light of current typological knowledge of the expression of negation. Developmental trends connected to the micro-typological variation are also discussed, Finnish dialects are compared with related and neighbouring languages, and relevant theoretical and methodological issues relating to the meeting point of typology and dialectology are addressed.

Keywords: typology, dialectology, negation, Finnish

Address: Helsinki Collegium for Advanced Studies, P.O. Box 4, FI-00014 University of Helsinki, Finland; matti.miestamo@helsinki.fi

\section{INTRODUCTION}

This paper will look at negation in Finnish dialects from a typological perspective. Focus will be on standard negation, i.e. the negation of declarative main clauses with a verbal predicate. 
The data will be mainly drawn from Savijärvi's (1977a) work on the dialectal variation Finnish shows in its negative construction. In recent years, the relationship between typology and dialectology, two mutually independent subdisciplines of linguistics, has received a fair amount of attention. The contributions in (Kortmann (ed.) 2004) and also some authors in (Nevalainen \& al. (eds.) 2006) address the points of contact between these disciplines and how bringing them closer together could benefit each of them.

Typology can be charactierized as world-wide comparative linguistics or the systematic study of cross-linguistic variation. Dialectology, on the other hand, typically looks at variation within a language, or in other words, studies variation between non-standard linguistic varieties that can be, according to given criteria, considered as dialects of one and the same language. As has been made clear in the many contributors to (Kortmann (ed.) 2004) dialectologists and typologists can learn from each other in many ways. To take some examples on a general level, typologists should make sure that their language samples are not biased towards standardized varieties in areas such as Europe, and dialectology could help in providing data on non-standard varieties. Dialectology can also provide typologists with a better understanding of the micro-level areal spread of linguistic features. Dialectologists, on the other hand, may benefit from typology in many ways: seeing the micro variation in the broader context of cross-linguistic variation helps to see the theoretical significance of the observed phenomena, and functional principles emerging from typological work may provide tools for understanding the nature of the variation. I will not engage in a longer discussion of the potential ways in which typologists and dialectologists might benefit each other's work, but I will take up some issues pertaining to the present topic in the discussion section of this paper.

The paper is structured as follows. Section 2 provides an overview of the relevant aspects of the typology of negation and looks at developmental trends in Uralic languages, and serves 
as a backgound for the examination of negation in Finnish dialects in Section 3. Section 4 will discuss issues at the interface of typology and dialectology arising from the treatment of negation in Finnish dialects, and conclude the paper.

\section{STANDARD NEGATION: TYPOLOGY, FINNISH AND URALIC LANGUAGES}

Typological work on negation has mainly concentrated on standard negation, but some other aspects of negation have also been addressed, most notably the negation of imperatives, the negation of existentials and non-verbal sentences, as well as negative indefinite pronouns (for an overview, see Miestamo 2007). In this paper I will focus on standard negation. The term standard negation refers to the basic ways that languages have for negating declarative verbal main clauses. A more precise definition to identify standard negation cross-linguistically is given in (Miestamo 2005:42):

A [standard negation] construction is a construction whose function is to modify a verbal declarative main clause expressing a proposition $\mathrm{p}$ in such a way that the modified clause expresses the proposition with the opposite truth value to p, i.e. $\sim$ p, or the proposition used as the closest equivalent to $\sim p$ in case the clause expressing $\sim p$ cannot be formed in the language, and that is (one of) the productive and general means the language has for performing this function.

Standard negation can be seen as a comparative concept in the sense of Haspelmath (2010). Note that identifying correspondences between affirmatives and negatives is not 
straightforward in all languages, which is taken into account in formulating the definition of the comparative concept.

Typological work on standard negation has paid attention to the type and position of negative markers, as well as to the structural differences between negatives and affirmatives beyond the presence of negative markers. Dahl (1979) and Payne (1985) have identified three main types of negative markers: negative particles, negative affixes and negative (auxiliary) verbs. Dryer $(1988,1992)$ has observed that negative particles tend to be preposed to the verb but that the placement of negative auxiliaries tends to correlate with basic word order: preposed to the verb in VO languages and postposed in OV languages.

In (Miestamo 2005), I looked at the structure of negatives more holistically and paid attention to structural differences between negatives and affirmatives in addition to the presence of negative markers, proposing a basic distinction between symmetric and asymmetric negation. Symmetry and asymmetry can be observed in constructions on the one hand and in paradigms on the other. In symmetric constructions, the only structural difference between negatives and their affirmative counterparts is the presence of the negative marker(s), whereas in asymmetric constructions, further structural differences are found. In symmetric paradigms, the correspondences between the members of the paradigms used in affirmatives and negatives are one-to-one, whereas in asymmetric paradigms they are not, and grammatical distinctions are often neutralized.

The Romanian examples in (1) exemplify both symmetric constructions and paradigms. The negatives differ from the corresponding affirmatives by the mere presence of the negative marker $n u$ and every affirmative form has its own unique negative counterpart. 
(1) Romanian (Indo-European, Romance) (constructed examples) ${ }^{1}$
a. (a) cânta 'to sing' PRES
b. (a) cânta 'to sing' IMPF

$\begin{array}{cllll} & \text { AFF } & \text { NEG } & \text { AFF } & \text { NEG } \\ \text { 1SG } & \text { cânt } & \text { nu cânt } & \text { cântam } & \text { nu cântam } \\ \text { 2SG cânți } & \text { nu cânți } & \text { cântai } & \text { nu cântai } \\ \text { 3SG cântă } & \text { nu cântă } & \text { cânta } & \text { nu cânta } \\ \text { 1PL cântăm } & \text { nu cântăm } & \text { cântam } & \text { nu cântam } \\ \text { 2PL cântați } & \text { nu cântați } & \text { cântați } & \text { nu cântați } \\ \text { 3PL cântă } & \text { nu cântă } & \text { cântau } & \text { nu cântau }\end{array}$

Asymmetric constructions are found, e.g., in Diola-Fogny (2) and Apalaí (3). In Diola Fogny (2), the negation of the future is expressed by a portmanteau marker combining the categories of future and negation. The marking of the future is thus different from its marking in the affirmative. In Apalaí (3), the negative marker is a deverbalizing suffix on the lexical verb, and the copula is added to carry the finite inflections.

(2) Diola-Fogny (Niger-Congo, Northern Atlantic) (Sapir 1965:33)
a. pan-i-man
b. 1et-i-man

FUT-1SG-want

FUT.NEG-1SG-want

'I will want.'

'I won't want.' 
(3) Apalaí (Cariban) (Koehn \& Koehn 1986:64)

a. isapokara $\quad[\varnothing]$-ene-no

jakuruaru.lizard [1>3]-see-IMPST

'I saw a jakuruaru lizard.'

b. isapokara on-ene-pyra a-ken

jakuruaru.lizard 3-see-NEG 1-be.IMPST

'I did not see a jakuruaru lizard.'

In both Diola-Fogny and Apalaí, the negative construction is not a simple matter of adding a negative marker to an otherwise identical clause. The negatives differ from the affirmatives in other ways than by the mere addition of negative markers and the constructions are thus asymmetric.

Asymmetric paradigms are found, e.g. in Maung (4) and in Burmese (5). In Maung the affirmative paradigm makes a distinction between realis and irrealis, but the negative has to use the irrealis verb form (the negative construction is symmetric since the negative marker is simply added before the irrealis verb form). The distinction between the realis and the irrealis is therefore lost in the negative. In Burmese, the affirmative can make a distinction between the actual, potential and perfect, but the suffixal negative marker replaces these markers and the distinctions are lost in the negative.

(4) Maung (Australian, Iwaidjan; Capell and Hinch 1970:67)
a. yi-udba
b. ni-udba-ji

1SG>3-put

1SG>3-put-IRR.NPST

'I put.'

'I can put.' 
c. marig ni-udba-ji

NEG $\quad 1 S G>3-p u t-I R R$.NPST

'I do not [/cannot] put.'

(5) Burmese (Sino-Tibetan, Burmese-Lolo; Cornyn 1944:12-13)

a. $\theta$ wâ-dé

b. Өwâ-mé

c. $\theta$ wâ-bí

go- $A C T$

go-POT

gO-PERF

'goes, went'

'will go'

'has gone'

d. ma- $\theta$ wâ-bû

NEG-go-NEG

'does/did/will not go, has not gone'

In both cases, the correspondences between the members of the affirmative and negative paradigms are not one to one and the paradigms are therefore asymmetric. In (Miestamo 2005), I found asymmetry in the construction in $46 \%$ of the sample languages and asymmetry in the paradigm in $30 \%$, while $40 \%$ did not show asymmetry at all. ${ }^{2}$

Asymmetric negation can be divided into subtypes according to the nature of the asymmetry (the percentages indicate how many of the sample languages exhibit each type of asymmetry): subtype A/Fin in which the lexical verb loses its finiteness in the negative (25\%, e.g. Apalaí), A/NonReal in which the negative differs from the corresponding affirmative in that it is marked for a category that denotes non-realized states of affairs (13\%, e.g., Maung), $\mathrm{A} /$ Emph in which the negative differs from the corresponding affirmative in that it is marked for a category that expresses emphasis in non-negatives $(2 \%$, thus marginal and not exemplified here), and A/Cat in which the marking of grammatical categories differs between affirmatives and negatives in other ways (33 \%, e.g., Diola Fogny and Burmese) - often 
grammatical distinctions are neutralized (as in Burmese). In Finnish, standard negation shows A/Fin asymmetry, and the remainder of this section will focus on that subtype.

In Standard Finnish, standard negation is expressed by a construction in which the negative auxiliary verb acts as the finite element of the clause, carrying person-number inflection, and the lexical verb loses its finiteness (6). Note that the impersonal passive form can be taken to be part of the person-marking paradigm and it is therefore included in the examples in (6). The present, past, conditional and imperative paradigms serve to illustrate the main aspects of the negative construction.

(6) Standard Finnish (constructed examples)

a. PRESENT, laulaa 'to sing'

AFF

1SG (minä) laulan

2SG (sinä) laulat

3SG hän laulaa

1PL (me) laulamme

2PL (te) laulatte

3PL he laulavat

PASS lauletaan

b. PAST, laulaa 'to sing'
NEG

(minä) en laula

(sinä) et laula

hän ei laula

(me) emme laula

(te) ette laula

he eivät laula

ei lauleta
AFF
NEG
1SG (minä) lauloin
(minä) en laulanut
2SG (sinä) lauloit
(sinä) et laulanut
3SG hän lauloi
hän ei laulanut 
1PL (me) lauloimme (me) emme laulaneet

2PL (te) lauloitte (te) ette laulaneet

3PL he lauloivat he eivät laulaneet

PASS laulettiin ei laulettu

c. CONDITIONAL, laulaa 'to sing'

\begin{tabular}{lll}
\multicolumn{2}{c}{ AFF } & NEG \\
1SG & (minä) laulaisin & (minä) en laulaisi \\
2SG & (sinä) laulaisit & (sinä) et laulaisi \\
3SG hän laulaisi & hän ei laulaisi \\
1PL (me) laulaisimme & (me) emme laulais \\
2PL (te) laulaisitte & (te) ette laulaisi \\
3PL he laulaisivat & he eivät laulaisi \\
PASS laulettaisiin & ei laulettaisi
\end{tabular}

d. IMPERATIVE, laulaa 'to sing'

\begin{tabular}{lll}
\multicolumn{1}{c}{ AFF } & NEG \\
2SG laula & älä laula \\
3SG laulakoon & älköön laulako \\
1PL laulakaamme & älkäämme laulako \\
2PL laulakaa & älkää laulako \\
3PL laulakoot & älkööt laulako
\end{tabular}

The negative auxiliary is $e$ - in all other TAM categories except the imperative in which it is $\ddot{a} l$-. In the present (6a), the lexical verb is in the connegative form, which consists of the verb stem without person-number inflection and involves the doubling of the initial consonant of the following word or, if the following word starts with a vowel, the optional appearance of a 
glottal stop at the word boundary. In the past (6b), the non-finite form of the lexical verb is the past participle form, which thus marks past tense in the negative and is itself also marked for number. The conditional paradigm (6c) shows that mood is also marked on the lexical verb, which is in the connegative form of the conditional. In the imperative (6d), the lexical verb is in the imperative connegative form, except in the $2^{\text {nd }}$ singular, in which the simple connegative form is used. The negative construction is asymmetric since the structure of the negative differs from the affirmative in other ways than the mere addition of a negative marker. ${ }^{3}$ The paradigm is symmetric since every affirmative form has its unique negative counterpart. ${ }^{4}$ The negative auxiliary construction of the Standard Finnish type is generally found in Finnish dialects, but the dialects also exhibit some interesting variation to this construction. Before going into the dialectal variation, I will briefly address cross-linguistic variation in negative verb constructions.

Negative verb constructions belong to subtype A/Fin of asymmetric negation. A preliminary characterization of the subtype was given above, but a more detailed definition is needed: In subtype A/Fin, the negative differs from the corresponding affirmative in that the lexical verb loses its finiteness, partly or totally, in one or more of the following ways: it becomes syntactically dependent on a finite element added in the negative, it is in a form primarily used as a syntactically dependent verb in the language, or it has nominal characteristics. Furthermore, a new finite element (copula, auxiliary verb) is added in most cases.

Subtype A/Fin can be further divided into subtypes. On the one hand, there are constructions in which the negative marker is the finite element added in the negative clause, i.e. it is a negative verb. On the other hand, there are constructions in which the negative marker is not the finite element of the negative clause, a non-negative finite element is usually added in the negative, and the negative marker is attached either to the lexical verb (as in 
Apalaí) or to the added non-negative finite element. Since the Finnish construction is a negative verb construction, I will focus on negative verb constructions (labeled as subtype $\mathrm{A} / \mathrm{Fin} / \mathrm{NegVerb}$ in the typology), and I will not pay more attention to the other subtypes of $\mathrm{A} /$ Fin here.

In (Miestamo 2005), I found negative verb constructions in $9 \%$ of the languages, most commonly in northern Eurasia and North America (more specifically in northwestern USA and southewestern Canada, as well as southern Mexico); they are also found in many Oceanic languages. The negative construction in Evenki (7) features the negative verb $e$ - as the finite element of the negative clause, and the lexical verb is in a participial form. In Tongan (8), the negative verb is not an auxiliary but a higher clause verb taking the clause expressing the negated content as its clausal complement.

(7) Evenki (Tungus) (Nedyalkov 1994:2)

a. nuyan min-du purta-va bū-che-n he ISG-DAT knife-ACC give-PST-3SG

'He gave me the knife.'

b. nuyan min-du purta-va e-che-n bū-re

he 1SG-DAT knife-ACC NEG-PST-3SG give-PTCP

'He did not give me the knife.'

(8) Tongan (Austronesian, Oceanic) (Churchward 1953:56)

a. na'e 'alu 'a siale

b. na'e 'ikai ke 'alu 'a siale

PST go ABS Siale

PST NEG SBJN go ABS Siale

'Siale went.'

'Siale did not go.' 
The distinction between negative auxiliaries and higher negative verbs is a salient division within the negative verb type. Since the negative verbs in Finnish are auxiliaries, higher negative verbs will not be treated in more detail here. Another point of variation that we may pay attention to is how the different verbal categories are distributed between the negative verb and the lexical verb. In the Standard Finnish negative construction (6), the negative verb carries person and number marking but all other verbal categories are marked on the lexical verb. Evenki shows a rather different picture, with almost all inflections carried by the negative auxiliary.

Finnish is not the only language in the Uralic family to exhibit a negative verb construction. The original negative construction reconstructed for Proto-Uralic is a negative verb construction in which inflectional categories appear on the negative auxiliary and the lexical verb is in the uninflected connegative form. In some Uralic languages this pattern is still found, e.g., in Nenets, the examples in (9) illustrating the marking of person and tense on the auxiliary.

(9) Nenets (Uralic, Samoyed) (Hajdú 1988:19)
a. śerta-dm?
b. ńī-dm? śerta?
do- $1 S G$
$N E G-1 S G \quad d o$
'I am doing.'
'I am not doing.'
c. śerta-damś
d. ńī-damś śerta?
do-1SG.PST
$N E G-1 S G . P S T \quad d o$
'I did.'
'I did not do.'

The negative construction has developed in different ways in different Uralic languages, and the distribution of inflectional categories on the auxiliary vs. the lexical verb varies from one 
Uralic language to another. In some of them, e.g., Estonian (10), the negative auxiliary has lost all inflectional marking.

(10) Estonian (Uralic, Finnic) (Kasik 1994:41-42)
a. loe-n
b. loe-d
c. loe-me
read-1SG
read- $2 S G$
read-1PL
'I read.'
'You read.'
'We read.'
d. ma ei loe
e. sa ei loe
f. me ei loe
ISG NEG read
2SG NEG read
1PL NEG read
'I don't read.'
'You don't read.'
'We don't read.'

In Estonian, despite the invariant form of the negative word, the lexical verb is still in a nonfinite form. It is thus clear that we are dealing with A/Fin asymmetry, and since the negative word has the effect of requiring a non-finite form of the lexical verb, it can be seen as the finite element of the negative clause, i.e. a negative auxiliary verb. In Mansi (11), the negative marker has lost its auxiliary status, and has been reanalysed as a negative particle, and at the same time, the lexical verb has become fully inflected, just as in affirmatives. The negative construction is now symmetric.

(11) Mansi (Uralic, Ugric) (Kálmán 1965:45, 53)
a. ti nē am wā- $\gamma-1-{ }^{u} m$
b. at wā- $\gamma-1-{ }^{u} m$
this woman 1SG know-PRES-OBJ-1SG
NEG know-PRES-OBJ-1SG
'I know this woman.'
'I don't know.' 
There is a drift in the Uralic language family from an original negative auxiliary construction with all categories marked on the auxiliary towards a non-inflected negative auxiliary, and ultimately to a symmetric construction with a negative particle (see also Tauli 1966; Honti 1997abc). A similar drift leading from a negative verb construction to a particle construction can be observed in Yuman languages (southwestern USA and northwestern Mexico). Many Yuman languages still have a negative verb construction, but, e.g., in Maricopa (Hokan, Yuman) the negative verb has become a suffix on the lexcial verb and the construction has become symmetric (see Gordon 1986:154-156).

Comrie (1981) proposes a hierarchy regulating the appearance of verbal categories on the negative auxiliary vs. the lexical verb:

Comrie’s hierarchy (1981)

IMPERATIVE $<\{$ TENSE $/$ PERSON $/$ NUMBER $\}<$ MOOD $<$ ASPECT $<$ VOICE

According to the hierarchy, the imperative is the most likely of inflectional categories to be marked on the negative auxiliary, and voice is the least likely one to be marked on the auxiliary, and vice versa for the lexical verb. If a category is marked on the negative auxiliary in a language, the categories to the left of it are also marked on the auxiliary. The Uralic drift from a fully inflected negative auxiliary to a non-inflected auxiliary follows the hierarchy.

Comrie's hierarchy is based on a survey of negative verb constructions in Uralic languages. In (Miestamo 2004), I showed that the hierarchy is valid for other language families as well, and not only for negative verb constructions, but also for the distribution of inflectional categories between the finite element and the lexical verb in other subtypes of A/Fin. In fact, apart from the special treatment of the imperative, it is in accordance with similar hierarchies concerning the distribution of categories between auxiliary/superordinate 
and lexical/subordinate verbs more generally than just in negative constructions (e.g., Noonan 1985; Cristofaro 2003). Much more could be said about the typology of standard negation in general and about negative verb constructions in particular, but this brief overview should suffice as a background for the treatment of Finnish dialects that we now turn to.

\section{STANDARD NEGATION IN FINNISH DIALECTS}

This section will look at standard negation in Finnish dialects against the typological background set in the preceding section. Savijärvi (1977a) has done thorough work on negation in Finnish dialects. The work is based on a comprehensive survey of the dialect materials available in archives, theses and publications. ${ }^{5}$ His analysis and organization of the data provides an excellent basis for a typologically oriented treatment of the topic.

In typological studies looking at the cross-linguistic variation in the encoding of a functional domain, the identification of the domain in each language is primarily based on function. In a typological study of negation, for example, one is looking for constructions the function of which is to express negation, $\mathrm{cf}$. the definition of standard negation given in Section 2 above. The same approach could naturally be adopted in a dialect study, looking at all constructions expressing standard negation in Finnish dialects. In this paper, however, focus is on one construction type - the negative verb construction - even if other construction types expressing standard negation might be found in Finnish dialects. Unlike in general typological studies, such an approach is possible and justified in a study focusing on related languages or dialects (cf. also Bisang 2004:19-20). In the present case, the focus is also dictated directly by Savijärvi's (1977a) focus on the negative verb construction. 
Savijärvi pays primary attention to the marking of inflectional categories on the auxiliary and the lexical verb. Furthermore, he also classifies his data according to the order of the subject and the auxiliary, as well as the presence vs. absence of an overt subject (full NP or pronoun). In what follows I will not pay attention to word order, but it may be noted that the order of the auxiliary and the lexical verb shows practically no variation in Finnish: the auxiliary precedes the lexical verb except in very rare cases that play no role in Savijärvi's material. Since Finnish is a VO language, the order of the negative auxiliary and the lexical verb conforms to the word order generalization mentioned in Section 2 above. Note also that Savijärvi only discusses cases in which the general form of the negative auxiliary, i.e. the $e$ form, is used, but leaves imperative negation with the $\ddot{a} l$ - form outside his study. Furthermore, his focus is on indicative mood and no systematic observations are made on mood marking. These choices are also reflected in the focus of this paper.

Opinions on the classification of Finnish dialects differ to some extent among researchers. In accordance with Savijärvi (1977a:48-49), this paper follows the division of Finnish dialects into two main dialect areas: Western and Eastern. The Western dialect area may be further divided into Southwestern, Southwestern transitional, Tavastian, Southern Ostrobothnian, Central and Northern Ostrobothnian, and Far Northern dialects. The Eastern area is further divided into Savonian and Southeastern dialects. Standard Finnish is not, as such, based on the speech of any specific area, but incorporates elements from various dialects.

The pattern familiar from Standard Finnish (6), whereby the negative auxiliary carries the marking of person and number and the lexical verb is responsible for the other categories, is generally found in dialects. A few examples from different dialects are given in (12). ${ }^{6}$ 
(12) Finnish, various dialects (Savijärvi 1977a)

a. mut mää e-n tiär

but 1SG.NOM NEG-1SG know.CNG

'but I don’t know' (Southwestern, p. 53)

b. te e-ttä oom myönnyk-kääs sitä

2PL.NOM NEG-2PL be.CNG sell.PST.PTCP.SG-NPI it.PART

'You haven't sold it after all.' (Central Ostrobothnian, p. 118)

c. ja toeset ku ei-vät kehanneet

and other.PL.NOM as NEG-3PL bother.PST.PTCP.PL

'and as the others didn't bother to' (Savonian, p. 147)

However, what makes things more interesting, Finnish dialects also show a fair amount of variation in their negative auxiliary constructions. I will now go through the types of variation giving examples of each. Attention is paid, on the one hand, to how the dialectal forms differ from the standard Finnish negative verb constructions exemplified above, and on the other, following the principles of the above typological classification, to how they differ from what would be the affirmative counterparts of the negatives in the dialects. The affirmative counterparts are naturally not available in the authentic materials from which the examples are drawn, and cannot therefore be given in the examples. It can, however, be noted that in general finite/lexical verbs in affirmatives distinguish three persons and two numbers; if the affirmatives corresponding to the negatives in the dialects discussed deviate from this standard pattern, this will be commented on in the text where relevant.

Firstly, it is quite common in many dialects to find a non-inflected negative verb. Examples from various dialects are given in (13). 
(13) Finnish, various dialects (Savijärvi 1977a)

a. ei mää tiär ollenka

NEG ISG.NOM know.CNG at.all

'I really don't know.' (Southwestern, p. 55)

b. ko te ei lähtenys saunaha

because 2PL.NOM NEG leave.PST.PTCP.SG sauna.ILL

'Because you didn't go to the sauna.' (Central Ostrobothnian, p. 119)

c. net ei taho

3PL.NOM NEG want.CNG

'They do not want.' (Far northern, p. 131)

As can be seen in these examples, the negative auxiliary is in its unmarked form, identical to the $3^{\text {rd }}$ person singular form, irrespective of the person and number of the subject. Typologically speaking, despite the fact that the negative auxiliary is not inflected, these examples still show A/Fin asymmetry, since the lexical verb is in a non-finite form and syntactically dependent on the negative marker. As the negative word is syntactically the finite element of the clause, acting as the head for the dependent lexical verb, it may be analysed as an auxiliary rather than a particle. In terms of Comrie's hierarchy, another category has been lost on the negative auxiliary (person-number) but none gained on the lexical verb.

This variant of the negative construction is parallel to the Estonian pattern in (10). An interesting point of typological comparison outside the Uralic family is found in Maasai (14) where past tense negatives use the invariant negative auxiliary eitu and the lexical verb loses the marking of tense, thereby becoming less finite. 
(14) Maasai (Nilo-Saharan, Nilotic) (Mol 1995:60, 70)

a. a-inos-a

1SG-eat-PST

'I ate.' b. eitu a-inos

NEG $\quad 1 S G$-eat

'I didn't eat.'

Historically, the Maasai past negative marker consists of the $3^{\text {rd }}$ person singular prefix and the negative auxiliary, but synchronically it is a frozen form.

Coming back to Finnish, the extent of the use of the non-inflected $\left(3^{\text {rd }}\right.$ singular) form in $1^{\text {st }}$ and $2^{\text {nd }}$ person is the largest in the eastern parts of the Southwestern dialect area, in the wedge of Savonian dialects separating Southern and Central Ostrobothnian dialects, in the transitional area between eastern Savonian and Southeastern dialects, and in the (now extinct) Savonian dialect of the Finnish population in Värmland in west central Sweden (a Finnish dialect spoken by settlers of Savonian origin in the middle of otherwise Swedish speaking territory) (see Savijärvi 1977a:183f.). In these dialects the non-inflected form can be used in all persons, but its frequency of use varies - only in the Värmland dialect did it become the dominant pattern, in the Southwestern and Ostrobothnian areas mentioned it occurs quite often, but its use is much rarer in the transitional area in the east. In dialect areas adjacent to these, the distribution of the non-inflected negative auxiliary is restricted to some personnumber combinations. In a large part of Finnish dialects the use of the non-inflected auxiliary in $1^{\text {st }}$ and $2^{\text {nd }}$ person is sporadic or non-existant. Note that the question does not arise in the third person singular which uses the unmarked form anyway, and that in the $3^{\text {rd }}$ person plural, the unmarked form may be analysed either as being completely uninflected or as showing only person but not number marking. In the $3^{\text {rd }}$ plural its use is very common in all dialects, and especially in Southwestern, Southwestern transitional, Far Northern, and in the Southeastern dialect of the Kannas area (Savijärvi 1977a:180). Note also that the use of a $3^{\text {rd }}$ 
singular verb form for $3^{\text {rd }}$ plural is not specific to negation, but happens commonly in affirmatives as well. according to Savijärvi (1977a:191-192), a non-inflected negative auxiliary is more common when followed rather than preceded by the subject; an overt subject is necessary with these non-inflected auxiliary forms.

The negative auxiliary may be unmarked for number, but still show person marking as in (15). This type is widespread in Southwestern dialects and also attested in the Southeastern dialects of Ingria. The paradigm of the negative verb in (16) is typical of Southwestern dialects (the paradigm is given with the subject pronoun following the negative verb).

(15) Finnish, Southwestern (Savijärvi 1977a:59)

mut me en antan myärö

but 1PL NEG.1 give.PST.PTCP.SG along

'But we didn't give up.'

(16) Finnish, Southwestern (Savijärvi 1977a:70)

$\begin{array}{ll}\text { 1SG en minä } & 1 \mathrm{PL} \text { en me } \\ 2 \mathrm{SG} \text { et sinä } & 2 \mathrm{PL} \text { et te } \\ 3 \mathrm{SG} \text { ei hän } & 3 \mathrm{PL} \text { ei he }\end{array}$

According to Savijärvi $(1977 \mathrm{a}: 59,61,70)$, the loss of number marking in the $1^{\text {st }}$ and $2^{\text {nd }}$ persons is due to regular sound changes, and since the use of $3^{\text {rd }}$ singular instead of $3^{\text {rd }}$ plural is a common development in Finnish dialects in general, the paradigm has ended up looking like (16). The presence of the subject pronoun naturally becomes more important in expressing the identity of the subject when the negative verb is not marked for number. 
Savijärvi (1977a:182) notes that these forms get a singular reading when no overt subject is present.

Yet another point of variation concerns the form of the lexical verb in past tense negatives: the participle form is often unmarked for number, i.e. a singular participle is used even with plural subjects, see examples in (17).

(17) Finnish, various dialects (Savijärvi 1977a)

a. e-mme-häm me menny ollenkaan NEG-1PL-PRAG IPL.NOM gO.PST.PTCP.SG at.all

'We sure didn’t go at all.' (Tavastian, p. 76)

b. miks-e-tte kohta ruattiks sanonu? why-NEG-2PL soon Swedish.TRA say.PST.PTCP.SG

'Why didn't you then say in Swedish?' (Southwestern transitional, p. 81)

c. ei-kä ne ol-lum muu-ta NEG-COORD they be-PST.PTCP.SG else-PART

'And they weren't anything else.' (Southern Ostrobothnian, p. 107)

According to Savijärvi (1977a:193-194), non-agreement of the participle is very common in Finnish dialects. In $1^{\text {st }}$ and $2^{\text {nd }}$ person plural examples in the materials examined by Savijärvi, the dialects of Southern and Central Ostrobothnia show only singular participles. Plural partiples have been best preserved in northern Finland and in the dialects of eastern border areas. To some extent the number marking on the participial is dependent on the marking of number elsewhere in the construction (on the auxiliary and the subject NP), but there is no hard and fast correlation between these. It should also be noted that the loss of number 
marking on the participle concerns not only negative constructions but is common in other, non-negative, verbal constructions using participles, e.g., perfects and pluperfects, as well.

All the dialectal variants of the negative construction seen so far can be analysed as A/Fin negative verb constructions, albeit with somewhat different distributions of inflectional categories on the negative auxiliary and the lexical verb, in accordance with Comrie's hierarchy (see Section 2). We have seen that the variants have all involved reductions in the marking of either person or number on the negative auxiliary or of number on the participial in past tense forms. However, in the Savonian dialect of Värmland, some examples are also found where the loss of marking on the auxiliary is compensated by a fully inflected lexical verb (18).

(18) Finnish, Savonian dialect of Värmland Forest Finns (Savijärvi 1977a:153)

a. ei minä lyö-n sinua

NEG $\quad$ 1SG.NOM hit-1SG 2SG.PART

'I will not hit you.'

b. ei minä sinua manoa-n

NEG 1SG.NOM 2SG.PART blame-1SG

'I will not blame you.'

As the negator is no longer inflected, and the lexical verb is in a finite form - thus no longer syntactically dependent on the negator - the negator cannot be analysed as a verb, but instead as a negative particle. The only structural difference between the negative and its affirmative counterpart is now the presence of the negative marker $e i$. In these examples we are therefore dealing with a symmetric negative construction formed with a negative particle, in the same way as in the Mansi example (11) above. 
In parts of the Tavastian dialect area a construction is found in the $3^{\text {rd }}$ person plural with an uninflected negative auxiliary and the lexical verb bearing the $3^{\text {rd }}$ plural person-number ending (19).

(19) Finnish, Tavastian (Savijärvi 1977a:96-97)

a. ei-kä nii vähä saa-vak-ka

NEG-COORD so little get-3PL-NPI

'nor will they get so little.'

b. syö-vät vs. ei syö-vät

eat-3PL NEG eat-3PL

'they eat.' 'they don't eat.'

c. ei taira-vat mennä

NEG seem.CNG-3PL go.INF

'They probably won't go.'

If we look at (19b), we can see that the negative differs from the affirmative by the mere presence of the negative marker. However, lexical verbs that involve morphophonological changes like consonant gradation reveal that the person-number ending is added to the connegative form rather than to the inflectional verb stem as such. Thus in (19c) the verb stem has the weak grade $r$ rather than the strong grade $t$ that would appear in the $3^{\text {rd }}$ person form taitavat and the construction seems to be a contamination of the $3^{\text {rd }}$ person negative ei taira and the $3^{\text {rd }}$ plural taitavat (see Savijärvi 1977a:95-100 for discussion). This is an unusual variant in the Finnish negation system, but judging from the form of the lexical verb, it still seems to involve A/Fin asymmetry, and can thus be analysed as a negative verb construction, not as a case of symmetric negation. 
Further examples that resemble symmetric negation are found in Southwestern dialects in the passive present tense forms (20).

(20) Finnish, Southwestern (Savijärvi 1977:64)

a. oteta

take.PASS.PRES

'one takes' b. ei oteta

NEG take.PASS.CNG

'one does not take'

This form is due to the effect of sound changes that have caused the passive present and passive connegative to fall together. The apparent symmetry concerns only an isolated item in a paradigm the other members of which are clearly A/Fin negative verb constructions. ${ }^{7}$ Therefore, we can hardly draw the conclusion that this would be a genuine case of symmetric negation with a negative particle (cf. the case of the $3^{\text {rd }}$ singular conditional in the Standard Finnish paradigm in (6c) above).

In Southwestern dialects, according to Savijärvi (1977a:64), it may happen that in the passive when both the connegative and the active past participle of the verb 'be' get apocopated to $\mathrm{ol}$, the distinction between these forms is lost, and consequently the perfect and the pluperfect that both use this verb as auxiliary are no longer distinguished (21).

(21) Finnish, Southwestern (Savijärvi 1977a:64)

a. ei stää olavils sit oll sanottu laijGaa NEG it.PART Olavi.ALL then be.PST.PTCP.SG said.PASS.PST.PTCP.SG at.all 'It hadn't been told to Olavi at all.' 
The apocopated past participle form of the verb 'be' oll is homophonous with its apocopated connegative form $o l$ in this dialect and this sentence could thus also get a perfect reading; cf. Standard Finnish: PASS.PERF on sanottu - PASS.PLUPERF oli sanottu vs. PASS.PERF.NEG ei ole sanottu - PASS.PLUPERF.NEG ei ollut sanottu. Apocope does not affect the distinction between the perfect and the pluperfect in the affirmative. This is the only point in the dialect material where paradigmatic asymmetry is found, and it is a straightforward result of phonological processes. It should, however, be emphasized that the paradigmatic asymmetry is a marginal phenomenon in these dialects and speakers can use fuller forms to disambiguate.

Savijärvi (1977b, 1981) has also paid attention to the occasional ellipsis of the negative auxiliary in negatives in the dialectal material. Sometimes the negative auxiliary is absent, and the asymmetry in the form of the lexical verb and possible negative polarity items present in the clause then convey the meaning of negation. Kotilainen (2007) shows how these dialectal cases of ellipsis have given rise to a colloquial construction expressing emphatic negation without an overt negator. In this context I will only note that (non-elliptical) negative constructions without overt negators are typologically extremely rare, see (Miestamo 2010) for more discussion.

The main types of dialectal variation in the Finnish negative verb construction have now been illustrated. These were: negative auxiliary and lexical verb inflected as in the standard language, non-inflected auxiliary, participial not marked for number in past negatives, and the Southwestern paradigm in which the negative auxiliary marks person but not number. In addition examples of symmetric negation were found in the Värmland dialect, as well as a marginal case of paradigmatic asymmetry in the Southwest. In the following section, this variation will be discussed in a broader typological-functional context. 


\section{DISCUSSION}

In this section, some interesting aspects of the dialectal variation in Finnish negation will be discussed in a broader context. I will start by coming back to the drift observed in the Uralic language family from a fully inflected negative auxiliary towards a non-inflected one and ultimately to symmetric negation. It has been observed that some dialects of Finnish have taken this development further than others, i.e. they have reduced or lost person-number marking on the negative auxiliary. Non-inflected forms were also present in early literary Finnish $\left(16^{\text {th }}\right.$ and early $17^{\text {th }}$ Centuries $)$, which is based on Southwestern dialects - one of the dialect areas showing non-inflected auxiliaries - (see Savijärvi 1977a:267f.), but have been replaced by the fully inflected forms in the course of the development of the standard language. It may be speculated that the drift towards non-inflected auxiliaries might have been able to progress further in spoken forms of Finnish without the effect of standardization slowing it down and stopping it.

The areal spread of non-inflected negative auxiliaries was briefly described above as culminating in the Southwestern dialects, in the Savonian dialects between Southern and Central Ostrobothnia, and in the Värmland Savonian dialects. It is notable that these are areas of high contact with Swedish. Swedish expresses standard negation with a negative particle in a symmetric negative construction and Swedish influence is an obvious candidate for an explanation of the non-inflected forms. In the case of the Värmland dialect, in which the noninflected auxiliary became the dominant pattern and even symmetric negatives with fully inflected lexical verbs were found, heavy contact with Swedish, possibly accompanied by effects of language attrition, seems a plausible explanation indeed. For the other cases, as

discussed by Savijärvi (1977a:188f.), it is more difficult to show that language contact could have been the main cause of the change, and developmental tendencies intrinsic to these 
dialects must also be taken into account. In any case, contact with Swedish has certainly supported and strengthened the development. Whatever the weight of the different factors at different stages of the development, this can be seen as part of the Uralic drift from fully inflected negative auxiliaries towards non-inflected negative words. Regular sound changes that are blind to the direction of the structural development may act as carriers of such a drift. In this case, the gradual change whereby fewer and fewer categories are marked on the negative auxiliary does not lead to a change in the basic type of the construction. Only when reanalysis of the negative auxiliary as a negative particle has happened and the lexical verb has simultaneously become fully inflected, has the construction shifted into the symmetric type.

Any asymmetry means more structural complexity vis-à-vis the symmetric type in which negative markers are simply added to the corresponding affirmative (see Miestamo 2006 for discussion). The shift into the symmetric type in the Värmland dialect can also be seen as a process of simplification. ${ }^{8}$ Given that this development has not been attested in any other dialect of Finnish, it seems plausible to attribute it not only to heavy contact with Swedish - a language with symmetric negation - but also to language attrition among the Värmland forest Finns; Värmland Finnish was a vanishing language when the data were gathered and the last speakers of died in the 1960's (Andersson \& Kangassalo 2003: 62-63).

In (Miestamo 2005), I proposed functional motivations for the existence of symmetric and asymmetric negation in terms of the notions of language-internal and language-external analogy (cf. Itkonen 2005). Symmetric negatives copy the structure of the corresponding affirmatives and are thus language-internally analogous to these; language-internal analogy is driven by pressure for cohesion in the system. Asymmetric negatives reflect, by languageexternal analogy, aspects of the functional-level asymmetry between affirmatives and negatives. These functional-level differences include the different discourse context of 
negatives vs. affirmatives and the more stative nature of the states of affairs reported by negative statements. A/Fin structures reflect the stativity of negation in their structure; this is clearer in cases in which the finite element added in the negative is a stative copula, but in negative verb constructions, too, stativity can be shown to have played a role since they can usually be traced back to a negative copular construction (see Honti 1997c for Uralic and Miestamo 2005:221-222 for more discussion). Language-internal analogy is doing its work in the drift leading towards symmetric negation.

A concern is sometimes raised about the representativity of the variants described in grammars consulted by typologists. Descriptive grammars can only address a small portion of the dialectal and social variation in a language if at all, and hence the picture that a typologist consulting these grammars gets is incomplete. Even worse, grammars dealing with standard written languages may not only miss the variation, but also describe a language variety that is an artificial construct and does not reflect the natural tendencies of that particular language or in language in general. Many authors have emphasized the importance of taking dialectal data into account to remedy the situation. Seiler (2004:368-369), for one, sees the benefits of dialectology to typology in that dialectology provides typologists with more grammars to compare and with grammars of non-standardized varieties, and adds a third aspect, namely that dialectology covers the whole continuum of areal variation and thus equips typologists with better data to tackle areal patterns. Coming back to negation in Finnish dialects, we have seen that the dialectal data does indeed give a richer picture of how negation works in Finnish. Furthermore, we find interesting areal patterns, with simplification of the morphology of the negative verb in high-contact areas, and signs of a development of a completely different negation type - symmetric negation - in a dialect isolated from other Finnish dialects and surrounded by Scandinavian languages with symmetric negation. 
One particular point in which dialect studies could help typologists working on negation to complement their data is the ellipsis of negators briefly mentioned above: descriptive grammars do not necessarily pay attention to such phenomena, and detailed dialect studies could benefit typologists in giving them material that would be hard to find in standard grammars.

How well a language variety described in a grammar - a doculect - represents the real linguistic variety of a given language is, however, not necessarily a problem from the point of view of typological sampling. Typological studies have different aims and different research questions, and different types of samples are used for different purposes. A study that aims at a general picture of the world-wide cross-linguistic variety in a structural feature uses a sample with a balanced representation of languages from different families and geographical areas. Adequate sampling methods should guarantee that the big picture is correct, although micro-variation gets obscured in the sampling process. By saying this I do not mean to undermine the importance of looking at dialectal variation in many other types of typological studies, let alone downplay the danger of standardized languages biasing the results of typological studies especially in their treatment Europe - a problem raised, e.g., by Fleischer (2004:236-237) and Himmelmann (2000:10-11).

I hope to have shown in this paper that, on the one hand, typology can offer new perspectives for understanding the nature of the negative verb construction in Finnish and the dialectal variation that it shows, and on the other hand, that looking at dialectal variation gives a more complete picture of the typology of Finnish. 


\section{ACKNOWLEDGEMENTS}

I am grateful to the audience at the Typology and Nordic dialect variation workshop in

Helsinki, June 2008, and the anonymous referees for their comments, to Pål Eriksen and

Camilla Wide for their editorial work, and to the Academy of Finland and the Helsinki

Collegium for Advanced Studies for financial support.

\section{NOTES}

1. The following grammatical category abbreviations are used in the examples in this paper: 1 - first person, 2 - second person, 3 - third person, ABS - absolutive, ACC - accusative, ACT - actual, AFF - affirmative, CNG - connegative, COORD - coordination, DAT - dative, FUT future, ILL - illative, IMPF - imperfective, IMPST - immediate past, INF - infinitive, IRR irrealis, NEG - negative, NOM - nominative, NPI - negative polarity item, NPST - nonpast, OBJ - object, PART - partitive, PASS - passive, PERF - perfect, PL - plural, PLUPERF pluperfect, POT - potential, PRAG - pragmatic marker, PRES - present, PST - past, PTCP participle, SBJN - subjunctive, SG - singular, TRA - translative.

2. The typology is based on the examination of a representative sample of 297 languages. The percentages are counted from a subsample of 179 languages in which the areal and genealogical balance of the sample languages is further adjusted.

3. It may be noted that in the conditional $3^{\text {rd }}$ singular, the connegative of the conditional is identical to the conditional $3^{\text {rd }}$ singular form used in the affirmative, and this particular negative-affirmative pair resembles symmetric negation; however, this is an isolated case in an otherwise clearly asymmetric system, and cannot be analysed as a genuine case of symmetric negation with a negative particle. 
4. Note that there is further asymmetry in negatives in that certain NPs in the scope of negation have to be in the partitive case whereas in affirmative sentences a choice can be made between nominative/genitive and partitive; in this paper, however, I will not discuss this case asymmetry and I will focus on the verbal construction instead.

5. Finnish language archives (e.g. Lauseopin arkisto at the University of Turku and Muotoopin arkisto at the Research Institute for the Languages of Finland and University of Helsinki) hold very extensive collections of dialectal materials.

6. The spellings have been unified to some extent. In Savijärvi (1977a), the symbol ü is sometimes used for the rounded close front vowel and the macron appears in some cases to mark vowel length. In this paper, long vowels are uniformly spelled with two letters and y is used for the rounded close front vowel.

7. An anonymous referee points out that the passive present and connegative forms cited here behave differently with regard to nasalization and sandhi phenomena in certain environments, so the apparent symmetry is even further limited.

8. An anonymous referee points out that similar simplified structures have been observed in the speech of L1 and L2 learners of Finnish.

\section{REFERENCES}

Andersson, Paula \& Raija Kangassalo. 2003. Suomi ja meänkieli Ruotsissa [Finnish and Meänkieli in Sweden]. In Hannele Jönsson-Korhola \& Anna-Riitta Lindgren (eds.), Monena suomi maailmalla. Suomalaisia kielivähemmistöjä [Finnish in many forms around the world. Finnish language minorities] (Tietolipas 190), 30-163. Helsinki: Suomalaisen Kirjallisuuden Seura. 
Bisang, Walter. 2004. Dialectology and typology - an intergrative perspective. In Bernd Kortmann (ed.), Dialectology Meets Typology: Dialect Grammar from a Cross-Linguistic Perspective (Trends in Linguistics. Studies and Monographs 153), 11-45. Berlin: Mouton de Gruyter.

Capell, Arthur \& H. E. Hinch. 1970. Maung Grammar (Janua Linguarum, Series Practica 98). The Hague: Mouton.

Churchward, C. Maxwell. 1953. Tongan Grammar. London: Oxford University Press.

Comrie, Bernard. 1981. Negation and other verb categories in the Uralic languages. In Osmo Ikola (ed.), Congressus Quintus Internationalis Fenno-Ugristarum, vol. VI, 350-355. Turku: Suomen kielen seura.

Cornyn, William. 1944. Outline of Burmese Grammar (Language Dissertation 38. Supplement to Language vol. 20, no. 4). Baltimore: Linguistic Society of America. Cristofaro, Sonia. 2003. Subordination. Oxford: Oxford University Press.

Dahl, Östen. 1979. Typology of sentence negation. Linguistics 17, 79-106.

Dryer, Matthew S. 1988. Universals of negative position. In Michael Hammond, Edith Moravcsik \& Jessica Wirth (eds.), Studies in Syntactic Typology (Typological Studies in Language 17), 93-124. Amsterdam: Benjamins.

Dryer, Matthew S. 1992. The Greenbergian word order correlations. Language 68, 81-138.

Fleischer, Jürg. 2004. A typology of relative clauses in German dialects. In Bernd Kortmann (ed.), Dialectology Meets Typology: Dialect Grammar from a Cross-Linguistic Perspective (Trends in Linguistics. Studies and Monographs 153), 211-243. Berlin: Mouton de Gruyter.

Gordon, Lynn. 1986. Maricopa Morphology and Syntax (University of California Publications in Linguistics 108). Berkeley: University of California Press. 
Hajdú, Péter. 1988. Die samojedischen Sprachen. In Denis Sinor (ed.), The Uralic Languages: Description, History and Foreign Influences (Handbuch der Orientalistik, achte Abteilung, Handbook of Uralic Studies, Vol. I.), 3-40. Leiden: Brill.

Haspelmath, Martin. 2010. Comparative concepts and descriptive categories in crosslinguistic studies. Language 86, 663-687.

Himmelmann, Nikolaus P. 2000. Towards a typology of typologies. Sprachtypologie und Universalienforschung 53, 5-12. [Special issue on Methodology in Linguistic Typology, ed. by Peter Siemund]

Honti, László. 1997a. Die Negation im Uralischen I. Linguistica Uralica 23(2), 81-86.

Honti, László. 1997b. Die Negation im Uralischen II. Linguistica Uralica 23(3), 161-176.

Honti, László. 1997c. Die Negation im Uralischen III. Linguistica Uralica 23(4), 241-252.

Itkonen, Esa. 2005. Analogy as Structure and Process: Approaches in Linguistics, Cognitive Psychology and Philosophy of Science (Human Cognitive Processing 14). Amsterdam: Benjamins.

Kálmán, Béla. 1965. Vogul Chrestomathy (Uralic and Altaic Series 46). Bloomington: Indiana University.

Kasik, Reet. 1994. Hakkame rääkima, viron kielen peruskurssi [basic course in Estonian] (Turun yliopiston suomalaisen ja yleisen kielitieteen laitoksen julkaisuja 37). Turku: Turun yliopisto.

Koehn, Edward \& Sally Koehn. 1986. Apalai. In Desmond C. Derbyshire \& Geoffrey K. Pullum (eds.), Handbook of Amazonian Languages, vol. 1, 33-127. Berlin/New York: Mouton de Gruyter.

Kortmann, Bernd (ed.). 2004. Dialectology Meets Typology: Dialect Grammar from a CrossLinguistic Perspective (Trends in Linguistics. Studies and Monographs 153). Berlin: Mouton de Gruyter. 
Kotilainen, Lari. 2007. Kiellon lumo. Kieltoverbitön kieltokonstruktio ja sen kiteytyminen [The fascination of negation. The negative construction without negative verb and its crystallization] (Suomi 193). Helsinki: Suomalaisen Kirjallisuuden Seura.

Miestamo, Matti. 2004. Suomen kieltoverbikonstruktio typologisessa valossa. Virittäjä 108(3), 364-368.

Miestamo, Matti. 2005. Standard Negation: The Negation of Declarative Verbal Main Clauses in a Typological Perspective (Empirical Approaches to Language Typology 31). Berlin/New York: Mouton de Gruyter.

Miestamo, Matti. 2006. On the complexity of standard negation. In Mickael Suominen, Antti Arppe, Anu Airola, Orvokki Heinämäki, Matti Miestamo, Urho Määttä, Jussi Niemi, Kari K. Pitkänen \& Kaius Sinnemäki (eds.), A Man of Measure: Festschrift in Honour of Fred Karlsson on His 60th Birthday (Special Supplement to SKY Journal of Linguistics, volume 19, 2006), 345-356. Turku: The Linguistic Association of Finland.

Miestamo, Matti. 2007. Negation - an overview of typological research. Language and Linguistics Compass 1(5), 552-570. (DOI:10.1111/j.1749-818X.2007.00026.x)

Miestamo, Matti. 2010. Negatives without negators. In Jan Wohlgemuth \& Michael Cysouw (eds.), Rethinking Universals: How Rarities Affect Linguistic Theory (Empirical Approaches to Language Typology 45), 169-194. Berlin: Mouton de Gruyter.

Mol, Frans. 1995. Lessons in Maa. A Grammar of Maasai Language. Lemek: Maasai Center. Nedyalkov, Igor. 1994. Evenki. In Peter Kahrel \& René van den Berg (eds.), Typological Studies in Negation (Typological Studies in Language 29), 1-34. Amsterdam: Benjamins. Nevalainen, Terttu, Juhani Klemola \& Mikko Laitinen (eds.). 2006. Types of variation: Diachronic, Dialectal and Typological Interfaces (Studies in Language Companion Series 76). Amsterdam: Benjamins. 
Noonan, Michael. 1985. Complementation. In Timothy Shopen (ed.), Language Typology and Syntactic Description, vol. II. Complex constructions, 42-140. Cambridge: Cambridge University Press.

Payne, John. R. 1985. Negation. In Timothy Shopen (ed.), Language Typology and Syntactic Description, Vol. I. Clause Structure, 197-242. Cambridge: Cambridge University Press.

Sapir, J. David. 1965. A Grammar of Diola-Fogny (West African Language Monographs 3). Cambridge: Cambridge University Press.

Savijärvi, Ilkka. 1977a. Itämerensuomalaisten kielten kieltoverbi I. Suomi [The negative verb in Finnic languages I. Finnish] (Suomalaisen Kirjallisuuden Seuran toimituksia 333). Helsinki: Suomalaisen Kirjallisuuden Seura.

Savijärvi, Ilkka. 1977b. Redundanssi ja kieltoverbin ellipsi suomen kielen negaatiojärjestelmäss ä [Redundancy and the ellipsis of the negative verb in the Finnish negation system] (Jyväskylän yliopiston suomen kielen ja viestinnän laitoksen julkaisuja 14.) Jyväskylä: Jyväskylän yliopisto.

Savijärvi, Ilkka. 1981. Redundanz und Ellipse des Negationsverbs im Negationssystem der finnischen Dialekte. In Heikki Leskinen (ed.), Heutige Wege der finnischen Dialektologie (Studia Fennica 24), 157-174. Helsinki: Suomalaisen Kirjallisuuden Seura.

Seiler, Guido. 2004. On three types of dialect variation and their implications for linguistic theory. Evidence from verb clusters in Swiss German dialects. In Bernd Kortmann (ed.), Dialectology Meets Typology: Dialect Grammar from a Cross-Linguistic Perspective (Trends in Linguistics. Studies and Monographs 153), 367-399. Berlin: Mouton de Gruyter.

Tauli, Valter. 1966. Strutural Tendencies in Uralic Languages (Indiana University Publications, Uralic and Altaic Series 17). The Hague: Mouton. 